This is an author produced version of a paper published in Environmental Monitoring and Assessment.

This paper has been peer-reviewed and is proof-corrected, but does not include the journal pagination.

Citation for the published paper:

Andreas C. Bryhn, Mikaela A. J. Bergenius, Peter H. Dimberg, Anders Adill. (2013) Biomass and number of fish impinged at a nuclear power plant by the Baltic Sea. Environmental Monitoring and Assessment. Volume: 185, Number: 12, pp 10073-10084.

http://dx.doi.org/10.1007/s10661-013-3313-1.

Access to the published version may require journal subscription.

Published with permission from: Springer.

Standard set statement from the publisher:

The final publication is available at link.springer.com.

Epsilon Open Archive http://epsilon.slu.se 
Self-archived version of

Biomass and number of fish impinged at a nuclear power plant by the Baltic Sea

By Bryhn et al.

Originally published in Environmental Monitoring and Assessment, December 2013, Volume 185, Issue 12, pp 10073-10084.

The final publication is available at link.springer.com.

http://link.springer.com/article/10.1007/s10661-013-3313-1

Please note that minor details may differ between the self-archived version and the original version.

Springer's rules on self-archiving at time of acceptance:

"Authors may self-archive the author's accepted manuscript of their articles on their own websites. Authors may also deposit this version of the article in any repository, provided it is only made publicly available 12 months after official publication or later. He/ she may not use the publisher's version (the final article), which is posted on SpringerLink and other Springer websites, for the purpose of self-archiving or deposit. Furthermore, the author may only post his/her version provided acknowledgement is given to the original source of publication and a link is inserted to the published article on Springer's website. The link must be accompanied by the following text: 'The final publication is available at link.springer.com'." 


\title{
Biomass and number of fish impinged at a nuclear power plant by the Baltic Sea
}

By Andreas C. Bryhn ${ }^{1 *}$, Mikaela A. J. Bergenius ${ }^{1}$, Peter H. Dimberg ${ }^{2}$ and Anders Adill ${ }^{1}$

${ }^{1}$ Swedish University of Agricultural Sciences, Department of Aquatic Resources, Institute of Coastal Research, Skolgatan 6, 74242, Öregrund, Sweden.

${ }^{2}$ Uppsala University, Department of Earth Sciences, Villavägen 16, 75236 Uppsala, Sweden

*Corresponding author: andreas.bryhn@slu.se

\begin{abstract}
The main aim of this study was to investigate the number and biomass of impinged fish at Forsmark Nuclear Power Plant in Sweden, located on the coast of the Baltic Sea. Of particular interest was the number of impinged individuals of the critically endangered European eel (Anguilla anguilla) which is regularly caught in the cooling system. Another aim was to determine the comparability of the results from Forsmark and results from impingement studies in other types of waters. Cross-systems studies make it possible to 1) estimate fish loss at plants where fish is not counted, and 2) to predict changes in fish loss from changes in electricity production or cooling water use. In 2010, 31,300,000 fish with a total biomass of 62,600 kg were impinged at Forsmark. In 2011, 27,300,000 fish weighing $38,500 \mathrm{~kg}$ were impinged. The maximum peak in total fish number and biomass occurred in spring. The most critical period for herring was in late summer and early autumn. Regarding eel, the largest impingement losses were recorded in November. The number of fish agreed with earlier established quantities of impinged fish in both freshwater and marine ecosystems. The study also estimated that 1,300 critically endangered eels could survive at Forsmark each year if a fish return system would be constructed to allow the passage of fish from the plant back to the Baltic Sea.
\end{abstract}

Keywords: fish; impingement; nuclear power; eel

\section{Introduction}

Large numbers of fish are impinged and killed in the cooling systems of thermal power plants worldwide (Kelso and Milburn 1979; Greenwood 2008; Azila and Chong 2010). The mortality of fish has been identified as the largest of the potential environmental concerns associated with cooling systems of nuclear power plants in Sweden (Ehlin et al. 2009; 2012). Once-through cooling water circuits take water from ecosystems nearby to control condenser process temperatures and release it back into the same system after use (Kelso and Milburn 1979; Greenwood 2008; King et al. 2010). Of the world's 463 nuclear power reactors, 373 (86\%) use water from natural ecosystems for once-through cooling-water circuits and the remaining reactors use other types of cooling (IAEA 2011). In thermal power plants, the number of impinged fish increases by an increasing amount of water required to cool reactor 
condensers (Kelso and Milburn 1979; Greenwood 2008; Azila and Chong 2010). The cooling water requirement is in turn correlated to the electrical effect (MWe) of the reactor (Kelso and Milburn 1979).

The removal of fish by power plants with once-through cooling systems has rarely exerted a demonstrable impact on surrounding fish stock sizes (Madenjian et al. 1986; Barnthouse et al. 2002; Newbold and Iovanna 2007; Greenwood 2008). An exception may be the Diablo Canyon Power Plant in California, U. S. A., which was found to remove about $40 \%$ of the clinid kelpfish larvae during entrainment, thereby affecting the adult population (Ehrler et al. 2002).

This paper concerns fish impingement in the cooling-water circuits at the Forsmark Nuclear Power Plant in eastern Sweden (fig. 1; $60^{\circ} 24^{\prime} 12^{\prime \prime} \mathrm{N}, 18^{\circ} 10^{\prime} 0^{\prime \prime} \mathrm{E}$ ). The aim is to quantify the biomass and number of impinged species, with a focus on dominating species and the European eel (Anguilla anguilla). The European eel stock stretches from North Africa to Northern Europe and it spawns in the western Atlantic, in or near the Sargasso Sea. The recruitment of European eel from the Atlantic is estimated to be at a historic minimum (EIFAAC and ICES 2011). The reason may be a combination of factors, such as climate change in the Sargasso Sea, habitat changes on the continents, overfishing, parasites and pollution (Bonhommeau et al. 2008). European eel is classified "critically endangered" by the IUCN (2012) and because of its poor ecological status, commercial catches of this species have been severely restricted. Recreational fishing of European eel is illegal in Sweden. Unlike Forsmark, at Ringhals Nuclear Power Plant on the west coast of Sweden, impinged fish is diverted back to the sea through a tube connected to a pumping system. The survival rate of European eel is particularly high compared to other species impinged at Ringhals; Andersson et al. (2011) estimated that $86 \%$ of the eel survive the stress caused by the passage. Taft (2000) also stressed that survival rates in fish return systems are highly species-dependent.

In coastal waters surrounding the Forsmark Nuclear Power Plant in Sweden, the heated effluent water from the cooling circuit of the plant has been shown to attract warm water fish species throughout the year (Neuman 1979). The heated effluent at Forsmark has also been related to negative physiological effects hampering fish reproduction (Lukšiené and Sandström 1994, Lukšiené et al. 2000) and egg survival (Sandström et al. 1997).

Impingement studies have been performed in many parts of the world (Ringger 2000; Greenwood 2008; Azila and Chong 2010), although impingement in nuclear power plants around the Baltic Sea has not been covered in the peerreviewed literature. Moreover, only a few studies (e. g., Kelso and Milburn 1979; Greenwood 2008) have attempted to compare impingement and other cooling system losses across systems. Cross-systems comparisons enable estimation of how much fish is lost at a plant where fish counting is not performed. Such comparisons can also be used to predict effects in fish loss from an increase or decrease in cooling water use of the plant.

In this study, we will determine the comparability of results from the Forsmark area (near a brackish ecosystem) and previously published results (in Kelso and Milburn 1979; Shao and Kuo 1988; Shao et al. 1990; Liao et al. 2004; 
Greenwood 2008) from plants which use cooling water from freshwater and marine systems, and also elaborate on how impingement studies at various types of aquatic ecosystems can be made more comparable in the future. We will, in addition, assess the extent to which the biomass and number of the impinged fish could change by a proposed increase in cooling water use at Forsmark.

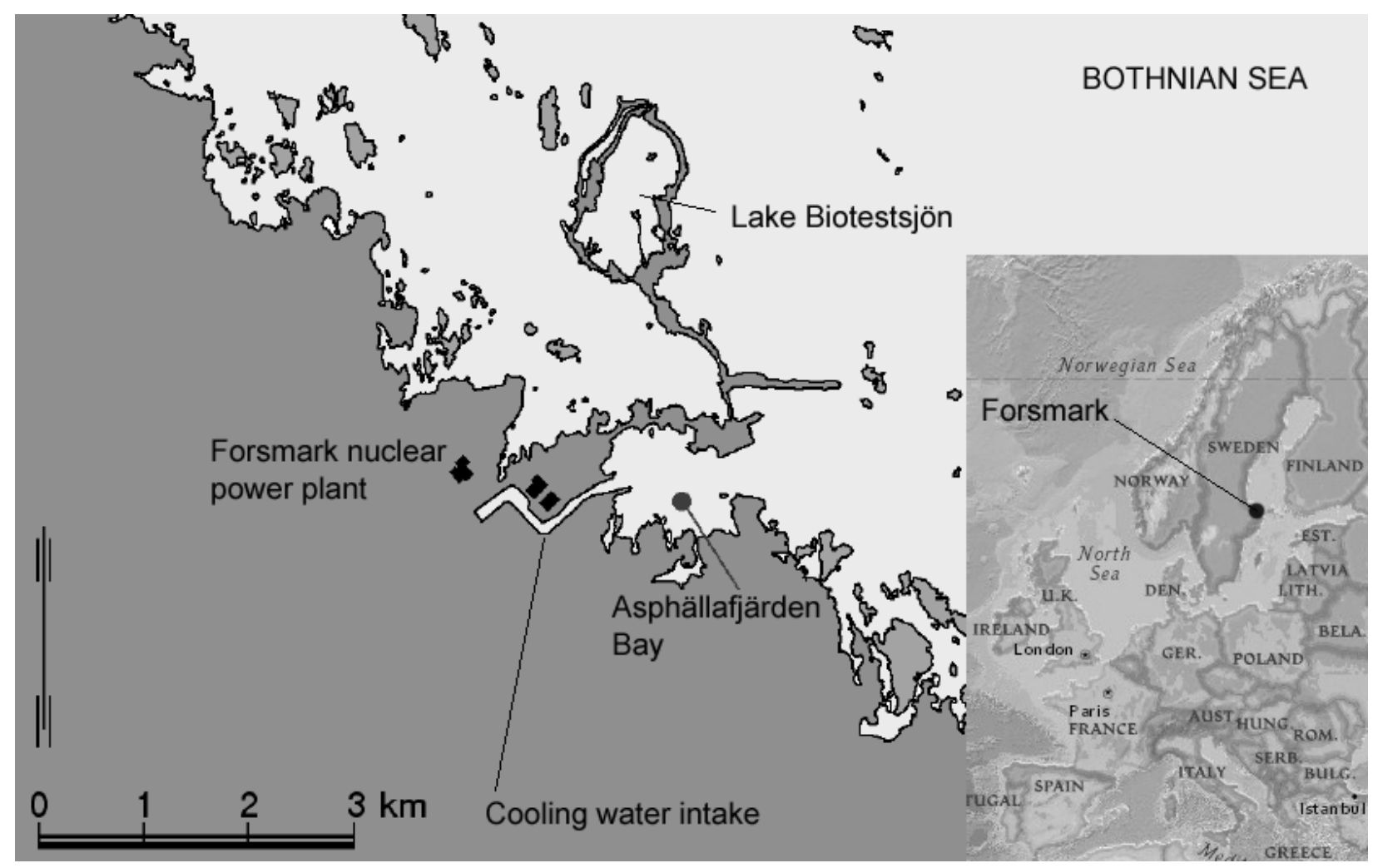

Fig. 1. Forsmark nuclear power plant. Cooling water is taken from Asphällafjärden Bay. Effluent is released into Lake Biotestsjön. The inset (modified from ESRI Base Maps) shows the location of Forsmark in Europe.

\section{Background and methods}

Forsmark Nuclear Power Plant consists of three reactors (F1-F3) which started to operate between 1980 and 1985. The reactor condensers are indirectly cooled by $135 \mathrm{~m}^{3}$ brackish seawater per second and the flow was constant throughout the measurement period 2010-2011. There are preliminary plans to increase the cooling water use to 170 $\mathrm{m}^{3} / \mathrm{s}$ in 2020 as a consequence of a proposed increase in electricity production. The cooling water is led into the plant through a canal from the Asphällafjärden Bay, which is a part of the Bothnian Sea, a subbasin of the non-tidal estuarine Baltic Sea. The Bothnian Sea is mesotrophic and contains both marine and freshwater fish species. The salinity is approximately 5 psu in Asphällafjärden Bay. Salinity in the Baltic Sea can be considered stationary since the standard deviation of salinity measurements is typically about $5 \%$ of the mean value over the year. A quantitative background description of the Forsmark plant and its surrounding waters is provided in table 1. 
Table 2 compares the background data in table 1 with data availability in other studies on fish impingement in other thermal power plants. The standard procedure of studies reporting fish impingement in thermal power plants is to publish the amount of cooling water used and the number of impinged fish. In this study we also included additional data on, e. g., the biomass of impinged fish and minimum mesh size at the innermost filters or screens. The relevance of these data will be discussed in coming sections.

Table 1. Background data for the fish investigation at Forsmark nuclear power plant. When applicable, data are specified for the three Forsmark reactors F1, F2 and F3.

\begin{tabular}{|l|l|}
\hline Data and units & Value \\
\hline Latitude $\left({ }^{\circ} \mathrm{N}\right)$ & 60.4 \\
Period investigated & $2010-2011$ \\
Cooling water used $\left(\mathrm{m}^{3} / \mathrm{s}\right)$ & $135(44+44+47)$ \\
Electrical effect of power plant $(\mathrm{MWe})$ & $3,138(978+990+1,170)$ \\
Thermal effect of power plant $(\mathrm{MWt})$ & $9,156(2,928+2,928+3,300)$ \\
Salinity in water $(\mathrm{psu})$ & 5.0 \\
Chlorophyll-a in water $(\mu \mathrm{g} / \mathrm{l})$ & 3.2 (nearest HELCOM monitoring station*) \\
Minimum mesh size in filters $(\mathrm{mm})$ & 2.0 \\
\hline
\end{tabular}

* HELCOM station F64 (60 $\left.11^{\prime} 20^{\prime \prime} \mathrm{N}, 19^{\circ} 8^{\prime} 32^{\prime \prime} \mathrm{E}\right)$; average long-term concentration June-August.

Table 2. Published data in studies on fish impingement at once-through cooling systems of thermal power plants. MWt: thermal effect, $M W e$ : electrical effect, Chl-a: chlorophyll-a concentration in cooling water, $N_{\text {fish }}$ : number of impinged fish, $M_{\text {fish }}$ : biomass of impinged fish. "Yes" means that data were published and "No" means that data were not published.

\begin{tabular}{|l|l|l|l|l|l|l|l|l|}
\hline Plant name & MWt & MWe & $\begin{array}{l}\text { Cooling } \\
\text { water } \\
\text { use }\end{array}$ & Chl-a & $\mathbf{N}_{\text {fish }}$ & $\mathbf{M}_{\text {fish }}$ & $\begin{array}{l}\text { Mini- } \\
\text { mum } \\
\text { screen } \\
\text { mesh } \\
\text { size }\end{array}$ & Reference \\
\hline Forsmark & Yes & Yes & Yes & Yes & Yes & Yes & Yes & This study \\
Kapar & No & Yes & Yes & No & Yes & Yes & Yes & Azila and Chong (2010) \\
(15 different) & No & Yes & Yes & No & Yes & Yes & Yes & King et al. (2010) \\
Longannet & Yes & No & Yes & No & Yes & Yes & Yes & Greenwood (2008) \\
Doel & No & No & Yes & No & Yes & No & Yes & Maes et al. (2004) \\
Eems & No & Yes & Yes & No & Yes & No & Yes & Hadderingh and Jager (2002) \\
Calvert Cliffs & No & Yes & Yes & No & Yes & Yes & Yes & Ringger (2000) \\
(18 different) & No & No & Yes & No & Yes & No & No & Henderson and Seaby (2000) \\
Nanticoke & Yes & No & Yes & No & Yes & Yes & No & Wiancko (1981) \\
(89 different) & No & Yes & Yes & No & Yes & No & No & Kelso and Milburn (1979) \\
$1^{\text {st NPP }}$ & No & Yes & Yes & No & Yes & Yes & Yes & Shao et al. (1990) \\
$2^{\text {nd }}$ NPP & No & Yes & Yes & No & Yes & Yes & Yes & Liao et al. (2004) \\
$3^{\text {rd }}$ NPP & No & Yes & Yes & No & Yes & Yes & Yes & Shao et al. (1990) \\
\hline
\end{tabular}

At the Forsmark plant, there were two types of filters used in the sieving station at the time of the study in 20102011. The mesh size in the first coarse sieve filter was $40 \mathrm{~mm}$ and this filter prevented large organisms and obstacles from passing through. The inner band sieve filters had a mesh size of $2 \mathrm{~mm}$. Filters were cleansed automatically and the material was in general ground in a grinding mill at the plant and used as agricultural fertiliser. 
The number and weight of fish trapped in the sieving station were registered once per week throughout of the year for 24 hours at the time. During these 24 hour periods, all the trapped material was led past the grinding mill and collected. Large objects and other organisms than fish were removed manually. When only fish remained, the total volume of the sample was recorded. Because of the large number of fish impinged, only some representative fish from the sample were counted and classified. First, the entire sample was placed on a sorting table and divided into two categories: "large fish" (length $\geq 6-8 \mathrm{~cm}$ depending on species) and "remaining fish". All the large fish were classified and divided into different containers according to species. The total volume of the remaining small fish was subsequently measured and five one-litre random samples were taken. The next stage of the sorting process included the species determination of the small fish in the five one-litre samples. The weight of each individual from the large fish sample and from the five one-litre samples was recorded, as well as the number and average biomass of individuals from each species. During periods when large fish were particularly numerous, the total volume and total biomass of each species was recorded alongside the biomass of an approximately average size fish from the sample. The fish-counting was performed as an integral part of the nuclear power plant's monitoring program (Adill et al. 2012).

To obtain monthly fish impingement values, fish counted at the four or five 24 hour periods during each month were considered representative for all days in the month. The number of fish per month was subsequently obtained by summing the total number of fish counted, multiplying by the number of days in each month and dividing by the number of counting periods during the particular month. Monthly fish biomasses were calculated in a corresponding manner.

Herring landings in 2011 were 14,393 kg in the Forsmark area (ICES subdivision 29N, statistical rectangle 49G8; unpublished data from Havs och Vattenmyndigheten). This information was used to compare with the amount of herring impinged at Forsmark.

\section{Results}

The biomass and number of fish impinged at Forsmark in 2010 and 2011 were highly variable between months and seasons (figs 2 and 3). Three-spined stickleback dominated both in biomass and numbers during large parts of the investigated period. Exceptions (not visible in figs 2 and 3) occurred during August, September and October in 2011, when weekly peaks of herring dominated both in biomass and individual numbers. Smelt dominated the total fish biomass during one week in April, 2010 although three-spined sticklebacks were more numerous than smelt even during this week.

Impingement was greater in 2010 compared to 2011. During 2010, 31,300,000 fish were impinged at the sieving stations. The total biomass of the fish was $62,600 \mathrm{~kg}$, and the average biomass of an impinged fish was $2.0 \mathrm{~g}$. In 2011, 27,300,000 fish were impinged. The total biomass was 38,500 kg and the average individual biomass was 1.4 g. Table 3 gives the percentage of total biomass and total number specified for each of the 33 identified species or 
species groups during 2010-2011. This table also lists the peak season for species with pronounced seasonal peaks; e. g., herring was primarily impinged during summer and autumn (July-November) while silver bream and threespined stickleback were most common in sieving stations during springtime (March - May).
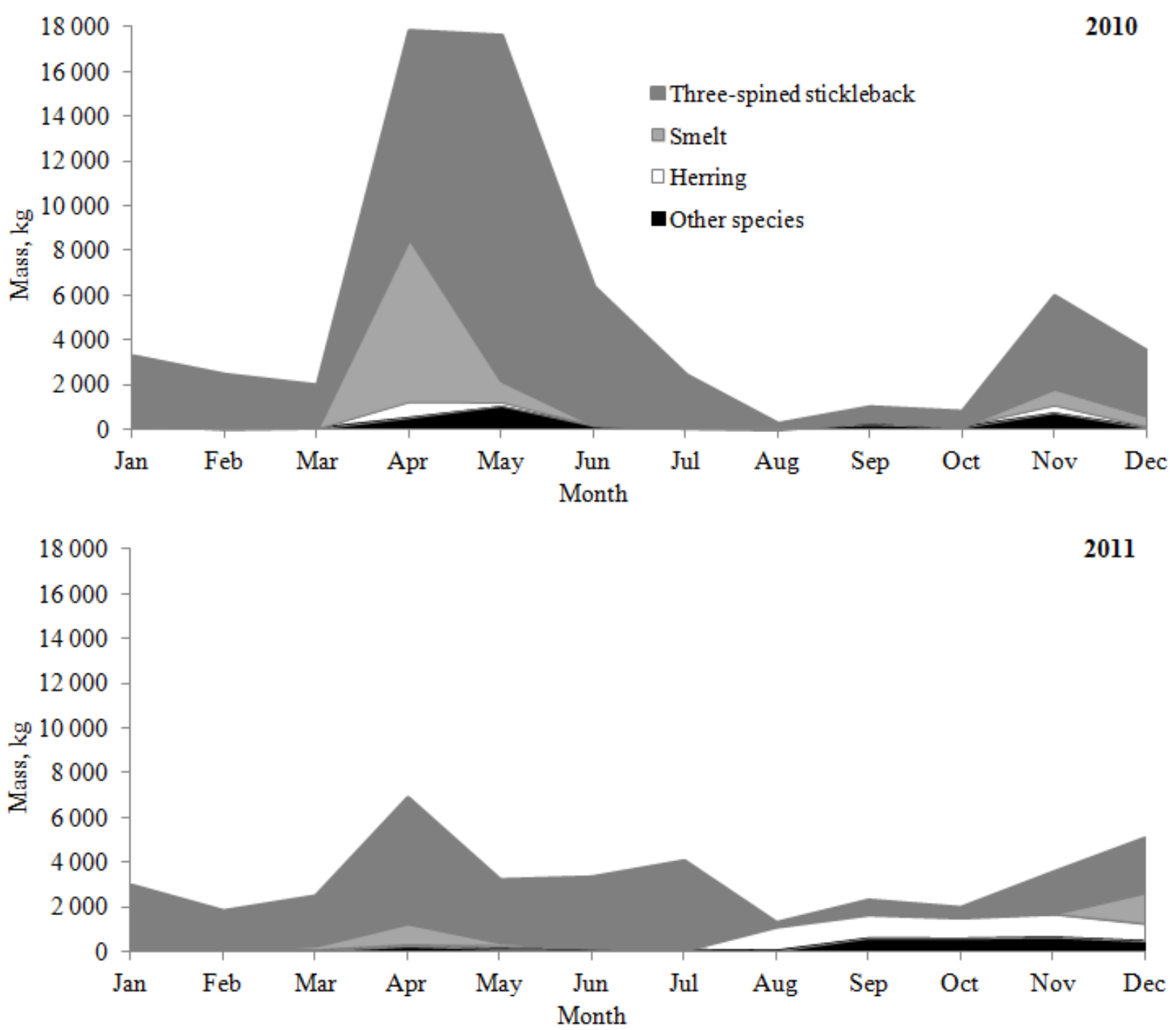

Fig. 2. Biomass of impinged fish at Forsmark nuclear power plant 2010-2011.

Fig. 2 shows that the minimum fish biomass occurred in August-October during both 2010 and 2011 although there was no corresponding minimum in the number of fish impinged (fig. 3). A closer look at the data concerning the three dominating species (three-spined stickleback, smelt and herring) revealed that the average biomass of fish individuals from these species was particularly low in August-October, significantly (at the 95\% confidence level) and approximately one order of magnitude lower than in April. 

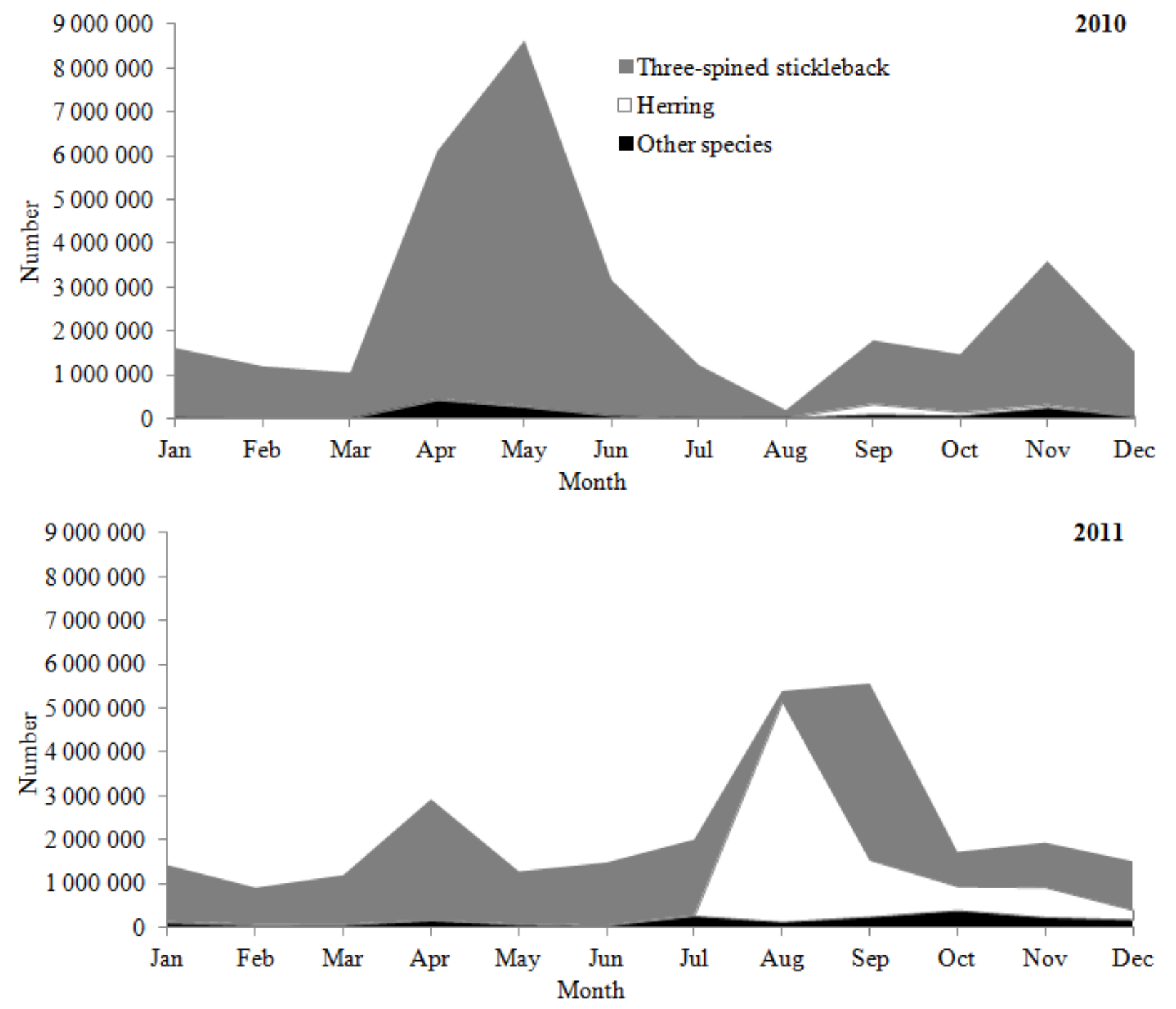

Fig. 3. Number of impinged fish at Forsmark nuclear power plant 2010-2011.

The impingement of eel (fig. 4) was greater in 2010 than in 2011. In 2010, 1,943 eels with a total biomass of 1,700 kg (average biomass per individual: $0.87 \mathrm{~kg}$ ) were impinged at Forsmark compared to 1166 eels with a total biomass of $950 \mathrm{~kg}$ (average biomass: $0.82 \mathrm{~kg})$ in 2011. If a fish return system would be built at Forsmark, ((1,943 eels + 1,166 eels) $/ 2$ years $\times 0.86$ [survival rate] $=1300$ eels could survive each year, assuming a constant survival rate (86 \%) as in Andersson et al. (2011). Impinged herring weighed 1,662 kg in 2010 and 5,216 kg in 2011. This corresponded to $11.5 \%$ and $36.2 \%$ of the herring landings in the Forsmark area in 2011.

Fig. 5 relates the Forsmark impingement data to impingement at plants located by tidal coastal waters in NW Europe (data from Greenwood 2008). The figure also includes mean values from investigations concerning three plants in subtropical and tropical Taiwan (data from Shao and Kuo 1988; Shao et al. 1990; Liao et al. 2004). The Forsmark data fit well into the regression and increased the $\mathrm{r}^{2}$ value by 1.8 percentage points to $0.535(\mathrm{p}<0.001$ in both cases; 
data not shown). However, including data from Taiwan's nuclear power plants (NPP), in particular the $3^{\text {rd }}$ plant, decreased the $\mathrm{r}^{2}$ value (fig. $5 \mathrm{~A} ; \mathrm{r}^{2}=0.284, \mathrm{p}=0.006$ ). Data from the $3^{\text {rd }} \mathrm{NPP}$ concerned an investigation for 24 months and had conspicuously low values. The data point was consequently considered an outlier and was removed from the analysis. This increased the $r^{2}$ value considerably to 0.451 ( $p<0.001$; fig. 5B).

Table 3. Fish species impinged in the once-through cooling-water circuit of Forsmark nuclear power plant 20102011. Fish counts documented 33 species or species groups. Peak seasons provided for species displaying strong seasonality.

\begin{tabular}{|c|c|c|c|c|}
\hline Scientific name & Common name & $\begin{array}{l}\text { Percent } \\
\text { of total } \\
\text { biomass }\end{array}$ & $\begin{array}{l}\text { Percent } \\
\text { of total } \\
\text { number }\end{array}$ & Peak season \\
\hline Gasterosteus aculeatus & Three-spined stickleback & 74 & 79 & Spring \\
\hline Osmerus eperlanus & European smelt & 12 & 0.67 & \\
\hline Clupea harengus & Herring & 6.9 & 15 & Summer-autumn \\
\hline Anquilla anquilla & European eel & 2.6 & $<0.01$ & Autumn \\
\hline Pungitius pungitius & Nine-spined stickleback & 1.1 & 3.4 & \\
\hline Perca fluviatilis & Perch & 0.6 & 0.037 & \\
\hline Rutilus rutilus & Roach & 0.53 & 0.028 & \\
\hline Alburnus alburnus & Common bleak & 0.51 & 0.62 & \\
\hline Abramis brama & Common bream & 0.46 & $<0.01$ & \\
\hline Gymnocephalus cernuиs & Ruffe & 0.24 & 0.015 & \\
\hline Pomatoschistus minutus & Sand goby & 0.17 & 0.68 & \\
\hline Ammodytes & Sandeel & 0.097 & 0.1 & \\
\hline Sander lucioperca & Zander & 0.097 & $<0.01$ & Summer \\
\hline Sprattus sprattus & Sprat & 0.066 & $<0.01$ & Autumn \\
\hline Triqlopsis quadricornis & Fourhorn sculpin & 0.065 & $<0.01$ & Winter \\
\hline Nerophis ophidion & Straightnose pipefish & 0.057 & 0.13 & \\
\hline Lampetra fluviatilis & European river lamprey & 0.036 & $<0.01$ & Winter \\
\hline Abramis bjoerkna & Silver bream & 0.03 & $<0.01$ & Spring \\
\hline Esox lucius & Pike & 0.027 & $<0.01$ & Summer \\
\hline Salmo salar & Salmon & 0.026 & $<0.01$ & Summer \\
\hline Coregonus maraena & Whitefish (maraene) & 0.022 & $<0.01$ & \\
\hline Zoarces viviparus & Viviparous eelpout & 0.02 & $<0.01$ & \\
\hline Psetta maxima & Turbot & 0.012 & $<0.01$ & \\
\hline Platichthys flesus & European flounder & 0.011 & $<0.01$ & \\
\hline Abramis vimba & Vimba bream & $<0.01$ & $<0.01$ & \\
\hline Carassius carassius & Crucian carp & $<0.01$ & $<0.01$ & \\
\hline Coregonus albula & Vendace & $<0.01$ & $<0.01$ & \\
\hline Gadus morhua & Cod & $<0.01$ & $<0.01$ & \\
\hline Gobius niger & Black goby & $<0.01$ & $<0.01$ & \\
\hline Liparis liparis & Common seasnail & $<0.01$ & $<0.01$ & \\
\hline Lota lota & Burbot & $<0.01$ & $<0.01$ & \\
\hline Spinachia spinachia & Fifteen-spined stickleback & $<0.01$ & $<0.01$ & \\
\hline Syngnathus typhle & Broadnosed pipefish & $<0.01$ & $<0.01$ & \\
\hline
\end{tabular}

Fig 6 compares the the total number of fish impinged at Forsmark at a given electrical effect (megawatt electrical; MWe) to impingement at thermal power stations with different electrical effects in the U.S.A. and Canada by the shores of the Great Lakes (from Kelso and Milburn 1979). By adding the brackish water data from Forsmark to this freshwater data set, the $\mathrm{r}^{2}$ value increased by 2.8 percentage points to 0.576 ( $\mathrm{p}<0.001$ in both cases; data not shown). Thus, the regression did not show any systematic difference in the MWe-impingement relationship between the 
Forsmark data and the freshwater investigation by Kelso and Milburn (1979). When data from Taiwan’s $1^{\text {st }}$ and $2^{\text {nd }}$ NPP were added, the $\mathrm{r}^{2}$ value decreased slightly to 0.575 ( $\mathrm{p}<0.001$; fig. 6$)$. There was no correlation between electrical effect and impinged fish biomass, or between water use and impinged fish biomass at the thermal power plants.
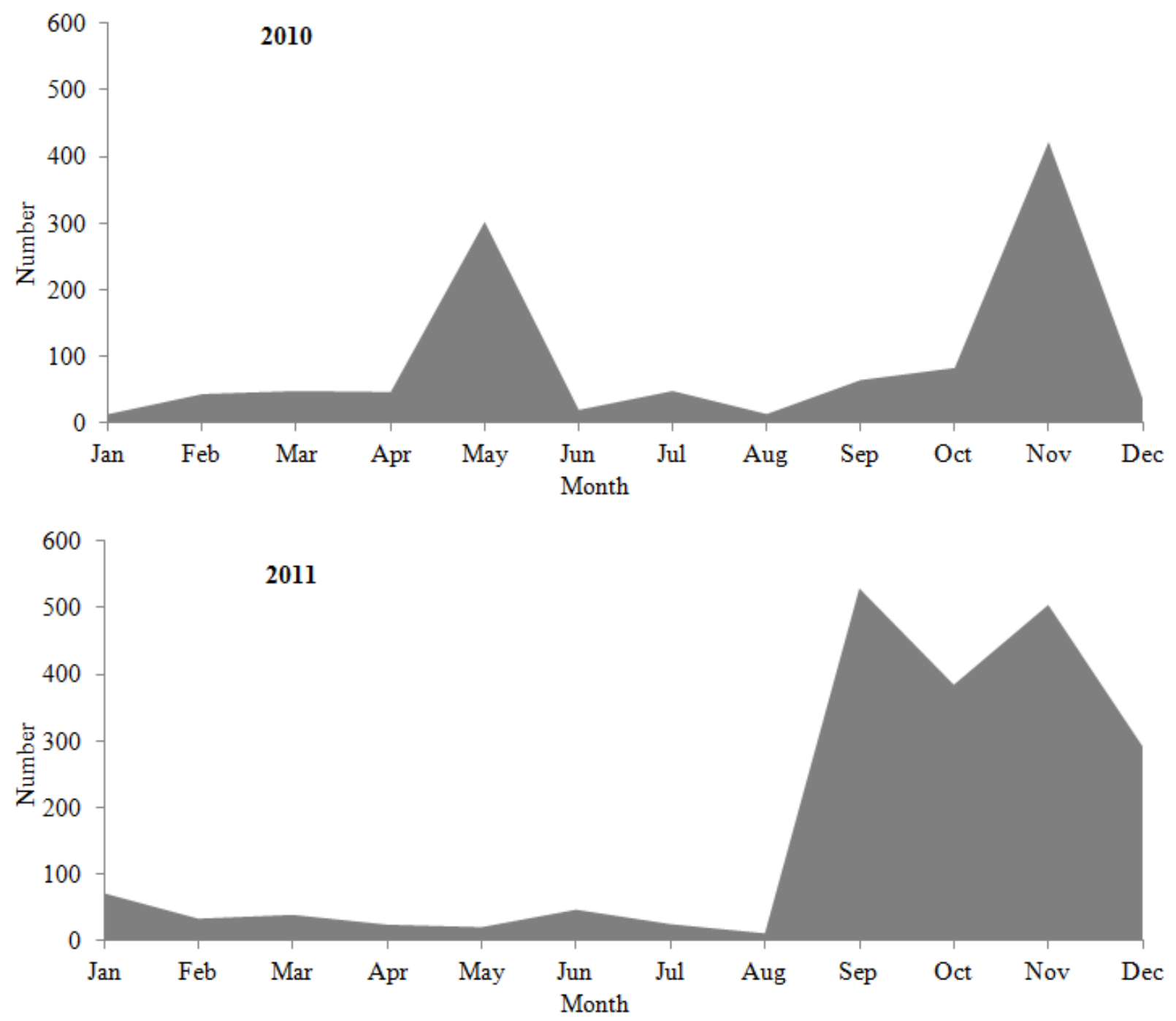

Fig. 4. Number of impinged European eel at Forsmark nuclear power plant 2010-2011. Average biomass was 0.85 $\mathrm{kg}$.

It was not possible to combine figs 5 and 6 because the $\mathrm{x}$-axis data were not compatible; cooling water use was not compared to fish impingement by Kelso and Milburn (1979) while MWe was not compared to impingement by Greenwood (2008), although cooling water use and MWe are correlated (Kelso and Milburn 1979). In addition, it was not possible to make any multiple regressions due to data scarcity. There was also no correlation between the minimum mesh size and average mass of impinged fish (data not displayed). 


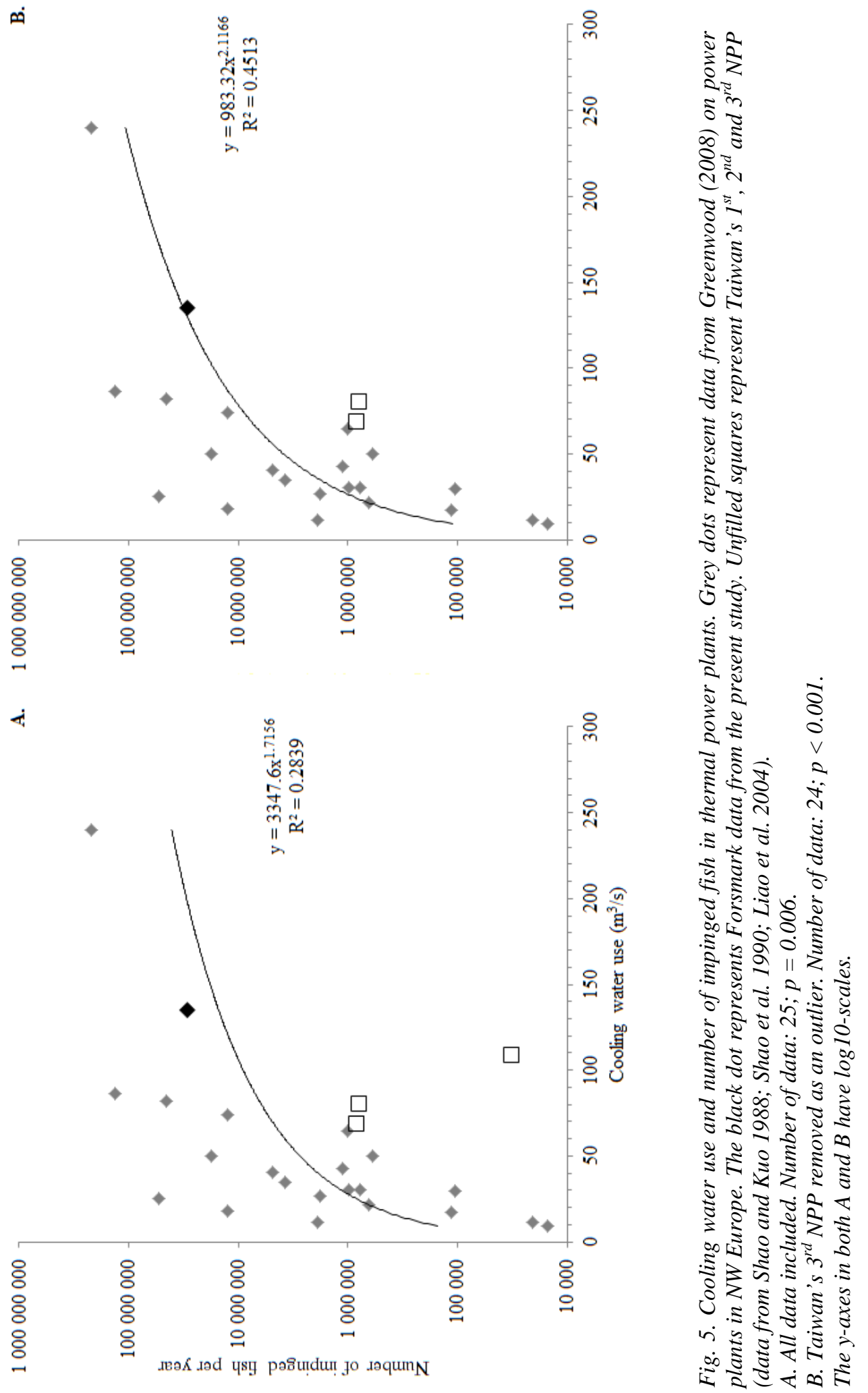




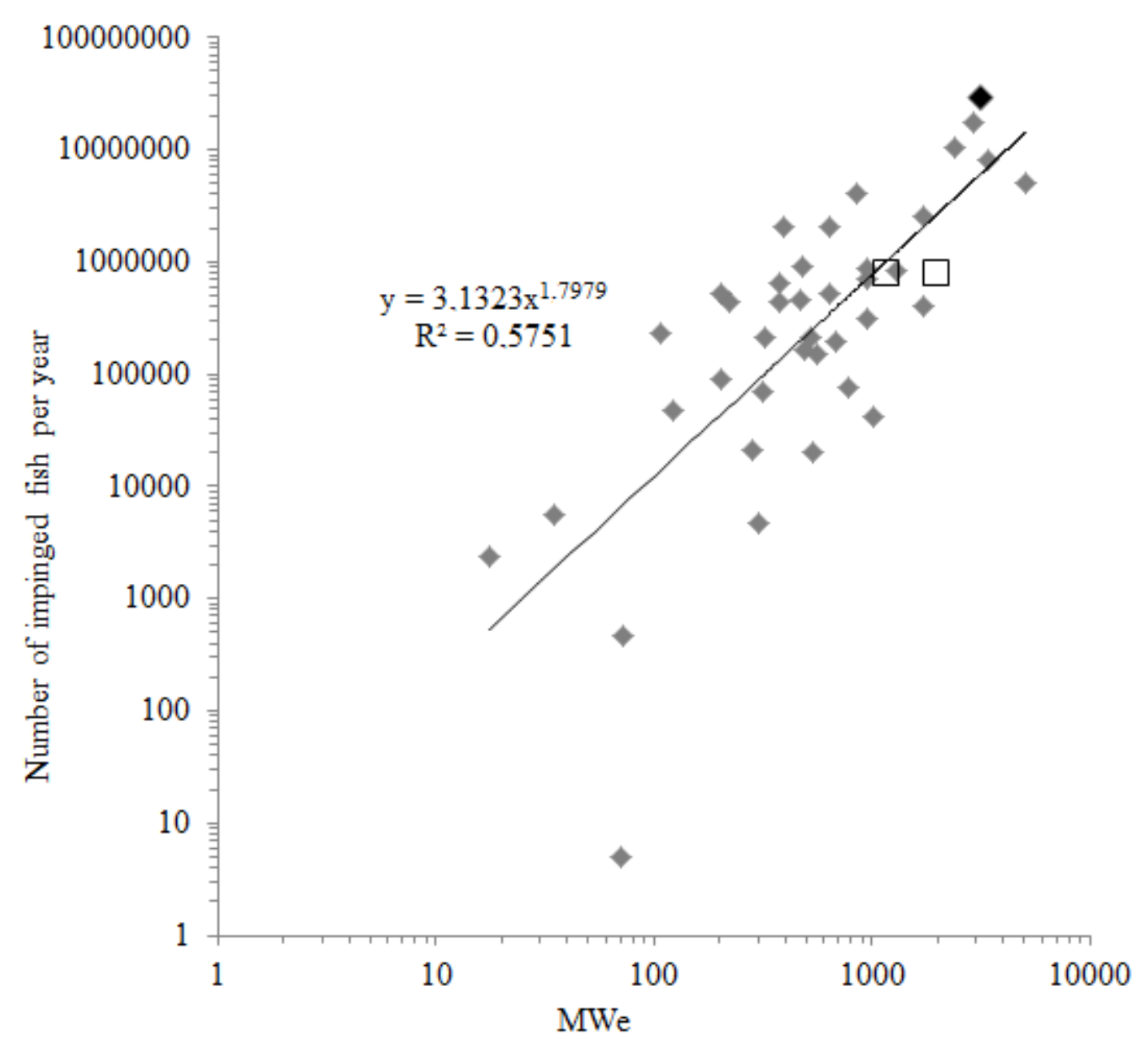

Fig. 6. Electrical effect (MWe) and number of impinged fish at thermal power plants. Grey dots represent data from Kelso and Milburn (1979) on power plants in the U.S.A. or Canada located on the shores of the Great Lakes. The black dot represents Forsmark data from the present study. Unfilled squares represent Taiwan's $1^{\text {st }}$ and $2^{\text {nd }} N P P$ (data from Shao and Kuo 1988; Shao et al. 1990; Liao et al. 2004). Number of data: 41; $p<0.001$. Both axes in the diagram have log10-scales.

Provided that the minimum mesh size and the mean biomass of individual fish remain, the equation in fig. 5B could serve as a model to predict some effects from the planned increase in cooling water use at Forsmark, from 135 to $170 \mathrm{~m}^{3} / \mathrm{s}$ (an increase by 26\%). According to the equation in fig. 5B, the number and biomass of impinged fish would then be a factor of $1.26^{2.1116}$ compared to present values, which is equal to an increase by $63 \%$. This means that the number of impinged fish would increase from 29.3 to 47.7 million per year. The biomass would increase from 50.5 to 82.3 metric tonnes per year.

\section{Discussion}

Three-spined stickleback dominated the biomass and number of fish impinged at the Forsmark plant in 2010 and 2011 (figs 2 and 3, table 1). This species has also been dominant and increasing in numbers during recent years in a wider range of waters surrounding the Forsmark plant (Karås et al. 2010; Adill et al. 2011). The increase has raised 
concern since an increasing number of three-spined stickleback may, through an increased competition for zooplankton, hamper the recruitment of larger predatory fish such as pike and perch in coastal waters of the Baltic Sea (Ljunggren et al. 2010). It is therefore possible that the impingement of three-spined stickleback at Forsmark decreases its abundance and is beneficial for pike and perch recruitment by decreasing the predation pressure on zooplankton.

Impinged herring has also caused concern, since herring is a commercially important species in the area and as some of the herring spawns in the vicinity of the Forsmark plant (Adill et al. 2011). Herring impingement in 2011 corresponded to more than $1 / 3$ of the weight of the herring landings in the area $(5,216 \mathrm{~kg}$ compared to $14,393 \mathrm{~kg})$. It should be stressed that the impinged herrings were mainly juveniles. Although herring in the Bothnian Sea currently are treated as they belong to one single unit in stock assessments, the population structure is not fully determined, particularly with regards to spring and autumn herring in the area. It is therefore unknown whether the impingement of herring may have an effect on the population and this warrants further investigation.

Figs 2 and 3 showed some seasonality and year-to-year difference in impinged fish number and biomass. This means that it is important to monitor impingement frequently in order to acquire representative data. Our data from 2011 are more consistent with earlier impingement investigations by Heibo and Karås (2005; two days per week during spring periods 1987-2004 and autumn periods 1986-2003) than with our 2010 data. Heibo and Karås (2005) showed a three-spined stickleback dominance in spring periods 1987-2004 and a herring dominance in autumn periods 1986-2003. Three-spined stickleback and smelt are generally spring-spawners in Sweden and the majority of herring also spawns during spring in the Baltic Sea (Kullander and Delling 2012). This pattern probably applies also to populations in the Forsmark area (fig. 2 and 3). The peak in herring number and biomass in August, 2011 (consistent with the pattern in Heibo and Karås 2005) is probably dominated by the young-of-the-year, as indicated by their low individual biomass. European eel abundance tends to peak in August at three sites further south along the Swedish Baltic Sea coast (Svedäng 1996). However, our results suggest that the peak at Forsmark occurs later in the year, around November (fig. 4). Regarding herring, the most sensitive period to impingement is probably late summer and early autumn (from this study, accounting for results in Heibo and Karås 2005) while the more critical month with regards to eel appeared to be November.

If a fish return system would be built at Forsmark similar to the one at Ringhals Nuclear Power Plant (see Background and methods), 1,300 eels per year which presently die at Forsmark could survive according to estimates in this study. There was no attempt made at estimating the economic cost or benefit of building a fish return system at Forsmark, although the current conservation status of the European eel, "critically endangered" (IUCN 2012), should motivate resolute and even costly action directed at saving eel. Autumn investigations of impinged eel at Forsmark reported by Ehlin et al. (2012) indicated an increase in both eel number and biomass between years 19912008. 
No correlations or trend shifts have hitherto been established between power plant activity and the abundance of any fish species in the Forsmark area. One explanation may be that more investigations are needed, and another may be that compensatory effects related to different competitiveness (e. g., different survival rates or spawning success) at different fish densities may prevent effects from impingement on some or several fish stocks to be distinguished (Henderson et al. 1984; Greenwood 2008). A third reason may be that the effect is too small to measure.

Impingement models can be used to estimate the fish loss at plants where fish is not counted, and also to predict changes in fish loss from changes in plant output or cooling water use. Such models may be uncertain because different geographical regions have different environmental characteristics and different fish communities. Additional explanatory variables could, however, increase the prediction accuracy of impingement models. For instance, a decreasing minimum mesh size in filters may increase the number of fish caught (Turnpenny 1981). Moreover, the chlorophyll-a concentration is a common proxy variable for primary production and fish production appears to be proportionate to primary production in lacustrine, estuarine and marine waters (Nixon 1982; Iverson; 1990; Houde and Rutherford 1993; Håkanson and Boulion 2002; Ware and Thomson 2005; Chassot et al. 2007; Jennings and Brander 2010). Minimum mesh size in the innermost filters and chlorophyll-a concentration could be included in future models as potential additional predictors of the number of impinged fish, although the results from such an inclusion are yet to be shown. Among the thirteen studies referred to in table 2, ten specify the minimum mesh size and only the present study specifies the chlorophyll-a concentration. Cooling water use and MWe are correlated at thermal power plants (Kelso and Milburn 1979) but it may nevertheless be beneficial for comparative studies to publish data on both cooling water use and MWe.

No model for investigating relationships governing the biomass of impinged fish at power plants could be developed or tested in this study. Such a model could be useful because other causes of fish mortality (e. g., commercial and recreational fishing) are often quantified and compared in terms of biomass per time unit. We recommend that all data types listed in table 2 are provided in future studies in order for more accurate and useful models to be developed. Figs 5 and 6 suggest that models can be developed for sites with very different environmental characteristics. The freshwater model from Kelso and Milburn (1979) as well as the model for tide influenced coastal ecosystems from Greenwood (2008) could both be successfully tested using data from the non-tidal estuarine Baltic Sea. However, data from subtropical Taiwan's $1^{\text {st }}$ and $2^{\text {nd }}$ NPP (Shao and Kuo 1988; Shao et al. 1990; Liao 2004) decreased the $r^{2}$ values in figs 5 and 6, indicating that there may be a systematic difference compared to temperate ecosystems regarding the impingement loss. This difference may warrant further investigation. The data point representing Taiwan's $3^{\text {rd }}$ NPP in the tropics (data from Shao et al. 1990) was removed as an outlier in fig. 5 and we believe that this removal was warranted due to a limited investigation time (24 months) with conspicuously low fish impingement numbers. Possibly, future investigations at this plant can determine whether and why data from this site deviate from the patterns in figs 5 and 6. 
The biomass and number of impinged or entrained invertebrates are currently not monitored at Forsmark, although this may be desirable in the future. Mussel larvae and jellyfish could pose a threat to the functionality of the plant. Entrained crustaceans could decrease the food availability for several fish species (Westin and Aneer 1987) while entrained fish larvae could affect fish reproduction (Kelso and Milburn 1979).

\section{Conclusions}

This study investigated the number and biomass of fish impinged during 2010-2011 at Forsmark Nuclear Power Plant located by the Baltic Sea. In 2010, 31,300,000 fish with a total biomass of 62,600 kg were impinged. In 2011, 27,300,000 fish weighing 38,500 kg were impinged. Three-spined stickleback, herring and smelt dominated among the fish. The results were used to test two different regression models for predicting the number of impinged fish using electrical effect and cooling water use, respectively, as predictors. The maximum peak in total fish number and biomass occurred in spring. The most critical period for herring was late summer and early autumn. Regarding eel, the largest impingement losses were recorded in November. If a fish return system would be built at Forsmark, approximately 1,300 critically endangered European eels could be saved annually. Finally, this study predicted that if cooling water use would increase at the Forsmark plant from 135 to $170 \mathrm{~m}^{3} / \mathrm{s}$, both the number and biomass of the fish impinged at the plant would increase by $63 \%$.

\section{Acknowledgements}

Comments from two anonymous reviewers have greatly improved previous versions of the manuscript. We are also thankful to the Forsmark Power Group (Forsmarks Kraftgrupp AB) which has voluntarily financed the data collection and has shared these data with us.

\section{References}

Adill, A., Mo, K. \& Sevastik, A. (2011). Biological recipient control at Forsmark Nuclear Power Plant. Annual report for 2010. Öregrund: Swedish Board of Fisheries (in Swedish).

Adill, A., Landfors, F., Mo, K. \& Sevastik, A. (2012). Biological recipient control at Forsmark Nuclear Power Plant. Annual report for 2011. Aqua Reports 2012:7. Öregrund: Swedish Agricultural University (in Swedish with English abstract).

Andersson, J., Cardinale, M, Fagerholm, B, Hjelm, J and Pettersson, E. (2011). Fish losses in the cooling water intakes of the Ringhals plant. Öregrund: Swedish Board of Fisheries (in Swedish).

Azila, A. and Chong, V. C. (2010). Multispecies impingement in a tropical power plant, Straits of Malacca. Marine Environmental Research, 70 (1), 13-25. 
Barnthouse, L.W., Heimbuch, D.G., Anthony, V.C., Hilborn, R.W., \& Myers, R. A. (2002). Indicators of AEI applied to the Delaware estuary. The Scientific World Journal, 2(S1), 169-189.

Bonhommeau, S., Chassot, E. \& Rivot, E. (2008). Fluctuations in European eel (Anguilla anguilla) recruitment resulting from environmental changes in the Sargasso Sea. Fisheries Oceanography, 17(1), 32-44.

Chassot, E., Mélin, F., Le Pape, O., \& Gascuel, D. (2007). Bottom-up control regulates fisheries production at the scale of eco- regions in European seas. Marine Ecology Progress Series, 343(1), 45-55.

Ehlin, U., Lindahl S., Neuman E., \& Sandström O. (2009). Environmental effects from large releases of cooling water. Elforsk Report 09:79. Stockholm: Elforsk (in Swedish).

Ehlin, U., Borenäs, K., Neuman E., \& Sandström O. (2012). Environmental effects from large releases of cooling water in a warmer climate. Elforsk Report 09:79. Stockholm: Elforsk (in Swedish).

Ehrler, C.P., Steinbeck, J.R., Laman, E.A., Hedgepeth, J.B., Skalski, J.R., \& Mayer, D.L. (2002). A process for evaluating adverse environmental impacts by cooling-water system entrainment at a California power plant. The Scientific World Journal, 2(S1), 81-105.

EIFAAC \& ICES (2011). Report of the 2011 session of the Joint EIFAAC/ICES Working Group on Eels. Lisbon: EIFAAC \& ICES.

Greenwood, M. F. D. (2008). Fish mortality by impingement on the cooling-water intake screens of Britain's largest direct-cooled power station. Marine Pollution Bulletin, 56(4), 723-739.

Hadderingh, R. H., \& Jager, Z. (2002). Comparison of fish impingement by a thermal power station with fish populations in the Ems Estuary. Journal of Fish Biology, 61(Suppl. A), 105-124.

Håkanson, L., \& Boulion, V. V. (2002). The lake foodweb - modelling predation and abiotic/biotic interactions. Leiden: Backhuys.

Heibo, E., \& Karås, P. (2005). The coastal fish community in the Forsmark area SW Bothnian Sea. SKB Report P05-148. Stockholm: SKB.

Henderson, P. A., Turnpenny, A. W. H., \& Bamber, R. N. (1984). Long-term stability of a sand smelt (Atherina presbyter Cuvier) population subject to power station cropping. Journal of Applied Ecology, 21(1), 1-10. 
Henderson, P. A., \& Seaby, R. M. H. (2000). Technical evaluation of US Environmental Protection Agency proposed cooling water intake regulations for new facilities. Technical report. Lymington: Pisces Conservation Ltd.

Houde, E. D., \& Rutherford, E. S. (1993). Recent trends in estuarine fisheries: prediction of fish production and yield. Estuaries and Coasts, 16(2), 161-176.

IAEA (2011). Operating experience with nuclear power stations in member states in 2010 - Data sheets. International Atomic Energy Agency. http://www-pub.iaea.org/books/IAEABooks/8585/Operating-Experiencewith-Nuclear-Power-Stations-in-Member-States-in-2010-2011-Edition-CD-ROM. Accessed May 16, 2013.

IUCN (2012). The IUCN Red List of Threatened Species 2012.2. www.iucnredlist.org. Accessed May 16, 2013.

Iverson, R. L. (1990). Control of marine fish production. Limnology and Oceanography, 35(7), 1593-1604.

Jennings, S., \& Brander, K. (2010). Predicting the effects of climate change on marine communities and the consequences for fisheries. Journal of Marine Systems, 79(3-4), 418-426.

Karås, P., Adill, A., Boström, M., Mo, K., \& Sevastik, A. (2010). Biological investigations at the Forsmark plant 2000-2007. FINFO 2010:2, Öregrund: Swedish Board of Fisheries (in Swedish).

Kelso, J. R. M., \& Milburn, G. S. (1979). Entrainment and impingement of fish by power plants in the Great Lakes which use the once-through cooling process. Journal of Great Lakes Research, 5(2), 182-194.

King, R. G., Seegert, G., Vondruska, J., Perry, E. S., \& Dixon, D. A. (2010). Factors influencing impingement at 15 Ohio River power plants. North American Journal of Fisheries Management, 30(5), 1149-1175.

Kullander, S. O., \& Delling, B. (2012). Chordates: ray-finned fishes. Uppsala: Swedish Agricultural University (in Swedish).

Liao, Y.-C., Chen, L.-S., Shao, K.-T., \& Tu, Y.-Y. (2004). Temporal changes in fish assemblage from the impingement data at the Second Nuclear Power Plant, northern Taiwan. Journal of Marine Science and Technology, 12(5), 411-417.

Ljunggren, L., Sandström, A., Bergström, U., Mattila, J., Lappalainen, A. et al. (2010). Recruitment failure of coastal predatory fish in the Baltic Sea coincident with an offshore ecosystem regime shift. ICES Journal of Marine Science, 67(8), 1587-1595. 
Lukšiené, D., \& Sandström, O. (1994). Reproductive disturbance in a roach (Rutilus rutilus) population affected by cooling water discharge. Journal of Fish Biology, 45(4), 613-625.

Lukšiené, D., Sandström O., Lounasheimo L., \& Andersson J. (2000). The effects of thermal effluent exposure on the gametogenesis of female fish. Journal of Fish Biology, 56(1), 37-50.

Madenjian, C.P., Jude, D.J., \& Tesar, F.J. (1986). Intervention analysis of power plant impact on fish populations. Canadian Journal of Fisheries and Aquatic Sciences, 43(4), 819-829.

Maes, J., Turnpenny, A. W. H., Lambert, D. R., Nedwell, J. R., Parmentier, A., \& Ollevier, F. (2004). Field evaluation of a sound system to reduce estuarine fish intake rates at a power plant cooling water inlet. Journal of Fish Biology, 64(4), 938-946.

Neuman, E. (1979). Temperature impacts on fish catch outside a cooling water release site in the Baltic Sea. Swedish EPA Report 1163. Stockholm: Swedish EPA (in Swedish).

Newbold, S. C., \& Iovanna, R. (2007). Population level impacts of cooling water withdrawals on harvested fish stocks. Environmental Science \& Technology, 41(7), 2108-2114.

Nixon, S. W. (1982). Nutrient dynamics, primary production and fisheries yields of lagoons. Oceanologica Acta, 4 (Suppl.), 357-372.

Ringger, T. G. (2000). Investigations of impingement of aquatic organisms at the Calvert Cliffs Nuclear Power Plant 1975-1995. Environmental Science \& Policy, 3(Suppl. 1), 261-273.

Sandström, O., Abrahamsson I., Andersson J., \& Vetemaa, M. (1997). Temperature effects on spawning and egg development in Eurasian perch. Journal of Fish Biology, 51(5), 1015-1024.

Shao, K.-T., \& Kuo, S.-R. (1988). Species composition and seasonal distribution of impinged fishes at the two intakes along the northern coast of Taiwan. Acta Zoologica Taiwanica, 2, 209-227.

Shao, K.-T., Lin, C.-P-, Ho, L.-T., \& Lin, P.-L. (1990). Study on the fish communities from northern and southern waters of Taiwan by analyzing the impingement data. Journal of the Fisheries Society of Taiwan, 17(2), 73-90.

Svedäng, H. (1996). The development of the eel Anguilla anguilla L. stock in the Baltic Sea: an analysis of catch and recruitment statistics. Bulletin of the Sea Fisheries Institute 3/96, 29-41. 
Taft, E. P. (2000). Fish protection technologies: a status report. Environmental Science \& Policy, 3(Suppl. 1), 349359.

Turnpenny, A. W. H. (1981). An analysis of mesh sizes required for screening fishes at water intakes. Estuaries, 4(4), 363-368.

Ware, D. M., \& Thomson, R. E. (2005). Bottom-up ecosystem trophic dynamics determine fish production in the North-East Pacific. Science, 308(5726), 1280-1284.

Westin L., \& Aneer, G. (1987). Locomotor activity patterns of nineteen fish and five crustacean species from the Baltic Sea. Environmental Biology of Fishes, 20(1) 49-65.

Wiancko, P. M. (1981). Environmental design and operation of Nanticoke thermal generating station. Journal of Great Lakes Research, 7(2), 96-104. 